\title{
LABOUR PRODUCTIVITY IN THE CROATIAN CONSTRUCTION INDUSTRY: IMPACT FACTORS FROM THE CLIENT'S POINT OF VIEW
}

Scientiffic paper / Znanstveni rad

\author{
Maja-Marija Nahod \\ University of Zagreb, Faculty of Civil Engineering, Assistant professor \\ Corresponding author: majan@grad.hr \\ Miran Knezović \\ mag.ing.aedif.
}

\begin{abstract}
Worker productivity impact factors are one of the most important success factors in the construction industry. Understanding the workers' personality and competence, measuring it and taking appropriate action can directly contribute and facilitate the goals of construction projects. Each worker has their own personality, perception, ability, and so on; they also have different expectations at work. In this paper, the previous researchers of impact factors for labour productivity from the client's point of view are briefly analysed. New research in Croatia was conducted and research from the United States and Turkey has been summarised. The differences in research methodologies are also explained. The US study included 40 factors that influence productivity of labour. The Turkish and Croatian studies were based on two groups of factors: economic and socio-psychological factors, 17 factors in total. The main contribution is the qualitative analysis and comparison of the research results in Croatia and Turkey. The economic factors are currently more important than socio-psychological ones in Croatia and Turkey. Knowing the importance of the factors for increasing productivity is the starting point for acting towards the successful realisation of a project. Therefore, further research and focus on this theme are very welcomed.
\end{abstract}

Keywords: worker productivity; socio-psychological factors; economic factors

\section{PRODUKTIVNOST RADNIKA U GRAĐEVINARSTVU REPUBLIKE HRVATSKE: FAKTORI UTJECAJA IZ PERSPEKTIVE KLIJENTA}

Sažetak: Utjecajni faktori produktivnosti radnika u građevinarstvu su jedan od važnijh faktora uspješnosti građevinskih projekata. Razumijevanjem osobnosti i kompetencija te mjerenjem i odgovarajućim djelovanjem na produktivnost, direktno se doprinosi i olakšava postizanje ciljeva u građevinskim projektima. Svaki radnik ima svoju osobnost, percepciju, mogućnosti, a i očekivanja. Ukratko su analizirana dosadašnja istraživanja utjecajnih faktora na produktivost iz perspektive klijenta (investitora). Sumarno su prikazani rezultati odabranih istraživanja u Americi i Turskoj. Za potrebe ovoga rada provedeno je analogno istraživanje u Republici Hrvatskoj. Objašnjena je razlika u metodologiji pristupa kod provedenih istraživanja. Američko istraživanje uključivalo je 40 faktora koji utječu na produktivnost radnika. Tursko i hrvatsko istraživanje baziralo se na dvjema grupama faktora: ekonomskim i sociopsihološkim, ukupno njih 17. Glavni doprinos je provedena kvalitativna analiza i usporedba rezultata u Hrvatskoj i Turskoj. Iz nje proizlazi da su ekonomski faktori zasad važniji od socio-psiholoških faktora produktivnosti rada. Poznavanje važnosti faktora za povećanje produktivnosti je preduvjet za planiranje djelovanja na uspješnoj realizaciji projekata. Stoga su daljnja istraživanja i fokusiranje na ovu temu itekako dobrodošli.

Ključne riječi: produktivnost radnika; socio-psihološki faktori; ekonomski faktori

Nahod, M.-M., Knezović, M. 


\section{INTRODUCTION}

Despite its long tradition, the construction industry has not changed in technological terms as much as other activities and specialties-even not as much as would be expected. Today, masons work in a very analogous way as their ancestors did many years ago. Although materials and technology have progressed, even robotics are reality, only a few parts of the construction industry can boast of benefiting from this progress while most other parts strongly depend on labour productivity. Therefore, the researching and better understanding the labour productivity impact factors is crucial to increase the project success in overall. It is important to note that the construction industry is much more specific in comparison to other industries. While the products change place during production in the majority of industries, people and machines are more static than dynamic. The construction industry is the other way around - the products (buildings, bridges, roads and similar) are static and upon completion remains in the place of creation, while people and machines are in constant motion. The construction experiences significant impacts from the open-air environment, the climate and the weather, as well as the seasonal character of some works. Those issues are the main reasons for witnesses the productivity of labour in construction industry at a very low level.

From 1995 to 2011, productivity in the construction industry was almost twice as low as that than in other manufacturing industries [1]. Obviously, this theme is unduly neglected. Productivity in the construction industry can generate significant benefits and income. The first phase is to analyse the state of the art; here, from the client's point of view. This paper is a small contribution to this effort and, therefore, is worthy of attention.

\section{LITERATURE REVIEW}

Many contributions have since been made to clarify the processes and productivity mechanisms in the construction industry; only few of them are related to discussing the impact factors of labour productivity from the client's point of view. Discussing the labour productivity in overall, for instance, it is proven that employees will be more satisfied with their work if the ratio of investment and gains are equally distributed for all workers [2, 3]. Adrian found that 10 a.m. is the most productive time of the day for work; Tuesday is the most productive weekday, whereas the Friday is the least productive; and, work performance can be reduced after $60-70$ minutes of work on the same activity [4]. Herzberg has proven that there are two groups of factors that impact labour productivity. The first concerns the extrinsic or hygiene factors, and the second concerns the other intrinsic factors (motivators) [5]. The extrinsic factors include working conditions, benefits and job security, and similar factors that prevent dissatisfaction. Intrinsic factors are related to business challenges, achievements, success, responsibility and advancement, which are considered as motivators for satisfaction. Fiske's study was based on individual personalities [6]. More than 20 individual traits are collected and grouped into the following five general traits: social adaptability, emotional control, conformity, intellect and expressing confidence. Civil engineers and clients can use the results of such a research to identify the workers' personality. For example, individuals with strong social flexibility will be more accepting of innovation in business than others. They will probably be more motivated to accept new challenges and will develop close friendships with colleagues. Individuals whose personality is like conformity can easily get used to any work conditions. To motivate them, the manager should ask them for suggestions and contributions to the project [6]. Although individuals have significantly unique needs, Halloran proved that there were three basic types of motivation that impact people and their productivity, which are: fear, motivation and attitude [7]. The presence of highly productive work plays a key role in achieving a successful project. Given that labour costs are a considerable part of the project's budget, management decisions that affect labour productivity can result in success or losses [8]. In the construction industry, over $40 \%$ of the total costs are for labour, which is a good reason to maximise their productivity [9]. A work group is the most important organisational unit on a construction site. Partly, because of the organisational nature of the construction production process, and partly because of the social and cultural environment from which the workers are drawn [10]. The level of worker's competencies, such as synergies of education and experience, affects productivity and satisfaction. Researchers have presented competence as a function of the following five variables: experience in a work, education and training, accuracy or precision of work, achieving the targeted goal and dexterity in work [11]. Researchers have discussed the difficulties in establishing

Nahod, M.-M., Knezović, M. 
a standard method to measure productivity in the construction industry, due to the complexity and uniqueness of most projects [12]. That is the main reason why there is no universally accepted productivity measurement standard, as well. It integrates the mathematical approaches and human behaviour, with many environmental and contextual impacts. On the one hand, uncertainty comes from the methods and techniques applied, and on the other side it concerns the human errors, definition of normal and average work and its condition. Selecting the representative workers is not easy and unambiguous in many cases, especially for works in difficult conditions. It can be roughly estimated that measuring productivity is a matter of cases and circumstances, or a matter of statistics and its reach of conclusions. Therefore, its conclusions and applying possibilities on the entire construction population of works are limited. Sweis points out that the challenge is also unrepeatable because of the issues that appear in the realisation of projects [13]. One of the possibilities to better get known the labour productivity is its perception by client's point of view, which was selected as an approach for further research.

\subsection{Previous researching of the labour productivity impact factors from the client's point of view}

Since productivity first began to be studied in the mid-twentieth century, many contributions have been made to clarify the processes and productivity mechanisms in the construction industry. This section discusses the studies that were previously performed in the United States (US) and Turkey [14]. These studies were used as the base for research that was conducted in Croatia in 2016, which was the main contribution to this paper. Research in the United States considered more factors than Turkish studies, while the Turkish studies considered factors through two main categories: economic and socio-psychological factors. Turkey and Croatia are both developing countries and, therefore, some overlaps are to be expected. On the other hand, the United States is a developed nation and construction superpower, which is constantly developing novel solutions.

Labour productivity in the Croatian construction industry does not have a high priority. Time and cost overruns have been identified but they have mostly not related to labour productivity. Construction work normative are not updated and are mostly the only indicators that can be used to clarify the formal composition and size of work units and groups. At the same time, the behaviours and productivity issues on the site are not considered.

\subsubsection{Turkish research}

This study was conducted in 82 construction companies [14]. The response rate was $44 \%$. The research was conducted face by face and through e-mails. The target group consisted of construction managers, civil engineers, architects and technicians involved in construction projects. There were two groups of considered factors: 5 economic factors and 12 socio-psychological factors. The economic factors include: regularity of salaries, size of salaries, social insurance, cash bonuses and job security. The socio-psychological factors include: labour discipline, health and safety work conditions, job satisfaction, competitive environment, relationships with colleagues, assigning responsibilities, sharing and solving the problems, social activities, cultural and national differences, participation of workers in decision making, job distance from residence and distance from urban centres.

The data was analysed and presented by frequency (\%) of responses, and the calculation used the Relative Importance Index $\left(R \|_{1}\right)$. The applied scale was $1-5$, where 1 represented the lowest and 5 the highest impact on worker productivity. The RII was calculated as follows:

$\mathrm{R}_{1}=\frac{\sum_{i=1}^{5} W_{i} X_{i}}{\sum_{i=1}^{5} X_{i}}(1 \leq R I I \leq 5)$

where $W_{i}$ is assessment for each factor $(1-5) ; X_{i}$ is the number of respondents who gave a certain grade; while " $i$ " represents the ordinal number of respondents.

To illustrate the results of these tests, the assessment was grouped into the following 5 intervals: $1.00-1.80$ for insignificant impact; $1.80-2.60$ for significant impact, 2.60-3.40 for very significant and higher than 4.20 for an extremely significant impact. The results showed that the main motivator in the Turkish construction industry is money, with $\mathrm{RI}_{1}=4.41$ (extremely important). Regularity of salary is at the top and the size of salary is the second significant factor for productivity. Other economic factors, such as job security and social insurance, have also significant impact on productivity.

Nahod, M.-M., Knezović, M. 
Regarding the socio-psychological factors, the greatest impact on work productivity was labour discipline $\left(R \|_{1}=4.17\right)$, health and safety conditions $\left(R \|_{1}=3.74\right)$, job satisfaction $\left(R \|_{1}=3.66\right)$ and competitive environment $\left(R \|_{1}=3.53\right)$. Distance from the place of residence $\left(R \|_{1}=2.56\right)$ and distance from urban centres $\left(R \|_{1}=2.45\right)$ are the least important factors. Other six socio-psychological factors are within the interval of significant impact.

\subsubsection{United States research}

Research regarding the impact factors of work productivity was conducted in 2009 in construction companies [15]. It was conducted through an Internet questionnaire and was sent by e-mail. There were 54 respondents $(21.2 \%$ of 254 invited), of which $28(11 \%)$ had valid records. The target participants were like the Turkish survey: construction managers, civil engineers, architects and technicians.

The method of ranking assumed that impact factors were conducted as well as the calculation of relative value index $\left(\mathrm{R} \|_{2}\right)$. $\mathrm{R} \|_{2}$ was calculated according the formula [16-18]:

$\mathrm{RI}_{2}=\frac{\sum W}{A} \times N$

where $W$ is the individual evaluation of each offered factor; scale is $1-4$ ( 1 is not applicable to productivity; 2 is does not impact productivity; 3 has an indirect impact; and 4 has a direct impact); $N$ is the total number of respondents (which in this case is 28); and, A is the highest score that a factor can get (in this case it is 4). The impact factors for work productivity include workforce factors, external factors, communication factors, resource and other factors. The workforce factors are: lack of experience, absenteeism, alcoholism, misunderstandings among workers, age, lack of competition among workers, disloyalty and personal problems (arranged according to the research results in order of importance).

Drinking alcohol is detrimental to the person and other workers nearby. Workers impacted by alcohol are more prone to errors, slow down the pace of the working group and are vulnerable to accidents.

A misunderstanding among workers can cause misallocation of responsibilities in projects. This often leads to mistakes and efficiency reduction.

Other factors are slightly less important for labour productivity in the construction industry. Ageing is at the fifth place in the group. It is an important factor for workers' allocation. Younger workers perform physically harder work and older workers perform tasks that require more experience and which are more demanding.

Surprisingly, personal problems are found as being less important in the entire collection of factors. They often lead to lower concentration and greater inclination of errors, injuries and conflicts with others.

The most essential element in the resource group and factors overall is a lack of necessary materials (RII $=558.00$, see Table 1), which refers to the unavailability of certain materials or too much time spent for their supply. This proved the results of an earlier study [19]. Poor procurement management of materials caused time over-runs for $18 \%$ of jobs on average. Since $30-40 \%$ of the total project cost is the procurement of quality materials, this should be one of the most important factors that can directly improve worker productivity. All construction processes largely depend on high-quality tools and equipment. Any interruption in the use of certain equipment will result in problems such as material supply and slowing or completely stopping working operations. Size and organisation of storage locations are also important for productivity. If they are not appropriate, then the workers will spend a lot of time looking for material supply.

Nahod, M.-M., Knezović, M. 
Table 1 Overall impact factors for work productivity [15]

\begin{tabular}{|c|c|c|c|c|c|}
\hline Order & Impact factor for work productivity & $\mathrm{RII}_{2}$ & Order & Impact factor for work productivity & $\mathrm{RI}_{2}$ \\
\hline 1 & A lack of required building materials & 558.00 & 21 & $\begin{array}{l}\text { Changes in the projects during } \\
\text { construction phase }\end{array}$ & 465.75 \\
\hline 2 & A lack of water and/or power supply & 552.00 & 22 & Deferred construction inspection & 448.50 \\
\hline 3 & Accidents during construction phase & 546.00 & 23 & Payment Delays & 442.75 \\
\hline 4 & $\begin{array}{l}\text { A lack of necessary } \\
\text { tools/equipment }\end{array}$ & 540.00 & 24 & $\begin{array}{l}\text { Changes in the project initiated by } \\
\text { investor(s) }\end{array}$ & 442.75 \\
\hline 5 & Poor lighting & 510.00 & 25 & Poorly defined project objectives & 442.75 \\
\hline 6 & Inadequate site conditions & 510.00 & 26 & Inadequate transport facilities & 438.00 \\
\hline 7 & Weather conditions & 510.00 & 27 & The complexity of the project & 437.00 \\
\hline 8 & Different conditions than planned & 504.00 & 28 & Inadequate building materials & 437.00 \\
\hline 9 & Location of material storage & 504.00 & 29 & $\begin{array}{l}\text { A misunderstanding between the } \\
\text { investor, contractor and designer }\end{array}$ & 431.25 \\
\hline 10 & Overtime work & 504,00 & 30 & Alcoholism & 425.50 \\
\hline 11 & Poor organisation of construction site & 492.00 & 31 & A misunderstanding between workers & 419.75 \\
\hline 12 & Lack of experience & 488.75 & 32 & Law application & 419.75 \\
\hline 13 & Control delays & 488.75 & 33 & Training & 414.00 \\
\hline 14 & Draft Variations & 488.75 & 34 & The age of workers & 408.25 \\
\hline 15 & Violation of safety issues on construction site & 486.00 & 35 & Disputes with the designer & 396.75 \\
\hline 16 & Unfinished drafts & 483.00 & 36 & An increase of the price of the material & 396.00 \\
\hline 17 & The quality of the work & 480.00 & 37 & Disputes with the investor & 391.00 \\
\hline 18 & Absenteeism & 477.25 & 38 & $\begin{array}{l}\text { The lack of competition among } \\
\text { workers }\end{array}$ & 379.50 \\
\hline 19 & Repeatable works & 471.50 & 39 & Disloyalty & 373.75 \\
\hline 20 & Changes in the projects during designing & 465.75 & 40 & Personal problems & 368.00 \\
\hline
\end{tabular}

\subsection{Review of the differences in research methodologies}

In the Turkish research [14], the index of relative importance was obtained by overall score, which is dimensioned to one respondent (averaged by the respondent). In the US survey, the index of relative importance is a percentage of the maximum score for a particular factor that impacts work productivity. In addition, the scale in the Turkish research goes from 1-5 and in the US research it goes from 1-4. Consequently, the research is comparable in relative but not in absolute values.

\section{RESEARCH IN CROATIA}

\subsection{Methodology and respondents}

In our research of work productivity in the Croatian construction industry, the chosen methodology is analogous to those conducted in Turkey (as described above). Turkey is under the scope of construction work and its method of doing business in the construction industry is closer to that in Croatia than in the United States. The attitudes and views facing Croatia also resemble the situation in Turkey. In addition, several comment sections were offered, which further enriched the research findings and enabled qualitative analysis.

Following the goal of this research, an appropriate questionnaire was designed. It was carried out in September 2016. The survey was sent to 1.500 randomly selected members of the Croatian Chamber of Civil Engineers by e-mail. A total of 157 responses (10.5\%) were collected. The respondents were: investors (3), supervisors (14), project managers (25), designers (35), contractors (76) and others (8). Regarding the results, their main activities and responsibilities include: buildings (77 of respondents), construction structures (64), construction management (51), roads (49), hydro technical construction (43), while the least represented were experts in soil mechanics and foundation (13) and materials (3).

Nahod, M.-M., Knezović, M. 


\subsection{Results}

The survey included the economic and socio-psychological factors of work productivity. Generally, the economic factors are shown to be more important than social-psychological factors. Relative Importance Index $\left(R \|_{1}\right)$ of economic factors $\left(R \|_{1}\right)$ was 3.87 , which is a very significant impact, while $\mathrm{R} \|_{1}=3.14$ for social-psychological factors was a significant impact according to the methodology adopted in the survey.

Statistically, it can be concluded that money remains the most important work productivity factor $\left(\mathrm{R} \|_{1}=4.35\right)$. The amount of salary is less important than regularity and safety of salary overall. Cash bonuses $\left(R \|_{1}=3.95\right)$ and job security $\left(R \|_{1}=3.79\right)$ follow. Social security has the least impact on work productivity $\left(R \|_{1}=3.31\right)$. Regarding the socio-psychological factors, it can be observed that the greatest impact on work productivity are job satisfaction $\left(R \|_{1}=4.17\right)$, relationship with colleagues $\left(R \|_{1}=3.85\right)$ and labour discipline $\left(R \|_{1}=3.55\right)$, which are within the very significant impact. Cultural and national differences $\left(R \|_{1}=2.32\right)$ and distance from urban centres $\left(R \|_{1}=2.25\right)$ are the least important factors.

The remaining seven socio-psychological factors are in the interval of significant impact. The most important research findings are described in the following subsections. Some of the factors are grouped (e.g. regularity and salary size). These results could be of great support to construction companies in Croatia and may help them to recognise the factors that most impact the labour productivity on the construction site.

\subsubsection{Economic factors: Regularity and salary size}

Salary is undeniably the most important reason for working, despite Herzberg's theory [5] that money is not a motivator. According Maslow's hierarchy of needs [20], salary often satisfies basic living requirements. Moreover, it provides social and self-esteem for individuals. Therefore, it is not surprising that the regularity and amount of salary is assessed as the most important impact factor for work productivity in Turkey and Croatia. Regularity and height of salary act as an entirety and are inseparable. Salary regularity can, to some degree, compensate its height in the countries such as Croatia.

Poor financial conditions caused dissatisfaction and consequently lower the work productivity. According to the Central Bureau of Statistics in Croatia, the average net salary for the construction sector in 2015 was $85 \%$ of overall average salary in Croatia. The authors of the Turkish survey [14] stated that the project managers realised the benefits of correspondence and emphasising the possibilities of salary increasing to workers even before work starts. They highlighted increasing enthusiasm as a result, especially in long-term projects.

\subsubsection{Economic factor: Cash bonuses}

To facilitate productivity, the arrangements for cash bonuses can be assembled. Usually it is performed in advance of work getting started. It is believed that it increases the work productivity and satisfaction, quality of working, shortens the run time and, therefore, reduces the total cost of the project. In the case of overdoing or at too frequent applying of this type of motivation, exhilaration can cease and productivity could be lost.

A cash bonus is rated as the third most important factor for work productivity. The respondents' emphasised that work productivity should be measured and accompanied with reward. In the Turkish survey, it is the fourth most important factor for work productivity, although less than $15 \%$ respondents in Turkey use this method. Almost half of the respondents use it sometimes, regarding Turkish survey.

The system of productivity evaluation and award must be fair and transparent. The better method is awarding by groups. Workers are then more encouraged to cooperate and try to avoid disputes regarding individual mistakes. In this case, all group members are rewarded or punished equally.

\subsubsection{Economic factor. Job security}

Job security increases work motivation. Turkey and Croatia have similar results in the importance of this factor $\left(\mathrm{R} \|_{1}=3.79\right.$ Croatia; $\mathrm{R} \|_{1}=3.69$ Turkey). The feeling of security is enhanced if there is interdependence between employer and employee. The Turkish survey also noted the practice of changing and releasing workers in the cases of lower productivity. This method surely decreases productivity and broader demotivates other workers because it creates a sense of job insecurity. These results are also indicated in the Croatian respondents.

Nahod, M.-M., Knezović, M. 


\subsubsection{Economic factor. Social security}

Social security contributions are a kind of direct, compulsory levies which are used to fund the social security of citizens, such as pension and health insurance. Contributions are normally paid from salaries (at the expense of employees, for example) and on the salary, while collecting the extra-budgetary funds whose function is to pay social insurance benefits to citizens. Social security is the third most important factor according to the Turkish survey, after regularity and height of salary, as a guarantee of future security (retirement). In countries with high rates of illegal labour, labour productivity is usually low. There are also workers who work just for paid social security in both Turkey and in Croatia.

\subsubsection{Socio-psychological factor. Job satisfaction}

The construction industry is not attractive because the work conditions are often very difficult. However, this industry provides a wide range of jobs for those who are willing and able to take responsibilities. Skilled workers have a wider choice of jobs, their job satisfaction is increased and thus they are more productive, and vice versa-less skilled workers have a smaller selection of activities which often lead to dissatisfaction and reduced efficiency.

This factor is in the third pace in Turkey $\left(R \|_{1}=3.66\right)$ and in the first place in Croatia $\left(R \|_{1}=4.17\right)$. Many respondents agreed that a satisfied worker is a good worker. The sooner that an employer recognises this, the more likely it is that the desired success will be achieved.

\subsubsection{Socio-psychological factor. Relationships with colleagues}

In the group with team spirit, motivation and work productivity are much higher than in an isolated environment. It is essential that workers develop friendships outside the working hours, especially if the construction sites are far away from urban centres. Workers are tied to a project for a certain time and they have an obligation to be as efficient as possible. This can be achieved with a pleasant environment. In societies dominated by different ethnic groups, religions and languages, such as Turkey, positive relationships among workers enhance their work productivity. However, a few of the project managers in Turkey did not agree with this. They noted that friendships among workers can strengthen their salary negotiations. In Croatia, the respondents emphasised the need for team collaboration and a healthy business environment.

\subsubsection{Socio-psychological factor. Working discipline}

One of the crucial conditions for a steady improvement of working habits in the construction industry is the existence of labour discipline on site. It should be first applied to senior management. It is essential that managers serve as an example to the workers, such as by starting work before the employees and ending work after them. Although authority is crucial in establishing discipline on site, site managers must take into account the personality of each worker because each worker reacts differently to a particular request and statement. The concept of labour discipline is essential for construction sites, especially in developing countries. Ultimately, without work ethics and assigning responsibilities, working discipline is not viable. This factor is the first most important factor in Turkey $\left(R \|_{1}=4.77\right)$ and third in Croatia $\left(R \|_{1}=3.55\right)$

\subsubsection{Socio-psychological factor. Assigning Responsibilities}

Providing opportunities for workers to work according to their initiative directly builds confidence and motivates workers in their future work. Technical staff are often hesitant to make decisions due to a lack of confidence. By giving them greater responsibilities, managers can greatly increase their productivity. The responsibility gives employees an incentive to discover their skills and capabilities. The opposite effect is achieved by excessive interference in the work of an individual or workgroup. This factor is similarly rated in Turkey $\left(R \|_{1}=3.34\right)$ and Croatia $\left(R \|_{1}=3.40\right)$. The respondents stressed the necessity to clearly define realistic expectations and tasks.

\subsubsection{Socio-psychological factor. Health and safety conditions}

Security has always been a priority at every construction site because the work by nature is often dangerous and responsible for many accidents. Injuries at work can damage the reputation of the company, reduce productivity and result in high costs. It is well known practice to engage $2 \%$ more workers that needed in order to avoid

Nahod, M.-M., Knezović, M. 
interruptions due to injuries and illnesses of workers. According to the research, injuries in the Turkish construction industry represented $10.5 \%$ of all injuries, while they represented $7.3 \%$ of all injuries in Croatia. This factor is fifth in Croatia $\left(R \|_{1}=3.38\right)$ and second in the Turkey $\left(R \|_{1}=3.74\right)$.

\subsubsection{Socio-psychological factor. Sharing and solving challenges}

An effective way of respecting workers is to involve them in solving specific problems. In such situations, the workers often have a greater sense of responsibility and commitment to the project. Although the assessment of this factor to work productivity is similarly assessed in Turkey and Croatia, the respondents' comments are very different. Turkish respondents argued that this approach is considered as a management weakness, while in Croatia it is a positive contribution, especially if the consultations with workers were retained at lower levels of problem solving.

\subsubsection{Socio-psychological factor. The participation of workers in decision-making}

This factor is very similar and slightly less significant in both countries. Workers often have a feeling an insufficient involvement in project planning. According to the principles of total quality management, productivity is reduced if management does not recognise the benefits of the employee's advice. However, it is difficult to follow this in practice because of the low education level of many of the workers and the negative attitude of the managers.

\subsubsection{Socio-psychological factor. The creation of a competitive environment}

Most workers achieve greater productivity in a competitive work environment. This environment can be created by strengthening any competing elements that exist between the workers. One good strategy is rewarding, but excessive rivalry and even conflicts must be avoided so that they do not harm the success of the project. It is also necessary to identify those workers who do not want to compete with their colleagues. In the Turkish research this was a very significant factor $\left(R \|_{1}=3.53\right)$, while in Croatia $\left(R \|_{1}=3.03\right)$ it was less significant.

\subsubsection{Socio-psychological factor. Distance from the residence and urban centres}

Both factors seem not to have immense importance for work productivity. All the Turkish respondents claimed that a greater distance between the construction site and residence or urban centre was better for work productivity. The reason for this was that the Turkish workers felt that greater isolation allowed them to devote more time to the project (apart from social activities and family obligations). However, there is a possibility that workers may get bored after a long period of isolation, which would lead to falling concentration and productivity levels. To avoid boredom, it is necessary to provide a quality social life outside working hours.

\subsubsection{Socio-psychological factor. Social activities possibilities}

At isolated construction sites, far away from urban centres, many workers expected that the company would organised social and relaxing activities for them. Although most of the construction works usually required great physical effort, the workers still require physical activities that help them to relax. This factor is assessed slightly higher in Turkey $\left(\mathrm{R} \|_{1}=3.19\right)$ than in Croatia $\left(R \|_{1}=2.56\right)$

\subsubsection{Socio-psychological factor. Cultural and national differences}

It is essential to achieve an understanding of each others' cultures, beliefs and languages among workers. It is expected that this issue is more challenge for workers from smaller and more conservative regions. Therefore, it is important for the site manager to carefully examine the workers, form working units and adopt a management style that is in line with the workers different customs. In Turkey this factor is significant $\left(\mathrm{RI} \mathrm{l}_{1}=3.18\right)$ and in Croatia it is less significant $\left(\mathrm{RI}_{1}=2.32\right)$, which is consistent with the fact that Turkey is a much more multicultural country than Croatia.

\section{CONCLUSION AND DISCUSSION}

Labour productivity impact factors form the client's point of view is only a simple topic at first glance. A detailed overview in section "3.2. Results" shows its complexity and breadth for research, and still more work is required if

Nahod, M.-M., Knezović, M. 
we are to improve the awareness of productivity impact factors. According to the conducted research (see Table 2, in Turkey, the social security (with $22 \%$ difference in RII), working discipline (with $17 \%$ difference in RII) and the creation of a competitive environment (with 17\% difference in RII) are significantly higher impact factors for labour productivity by the client's perspective than in Croatia. Opposite of this, job satisfaction (with $14 \%$ difference in RII), relationships with colleagues (with 14\% difference in RII) and social activities possibilities (with $25 \%$ difference in RII) are perceived as more important labour productivity impact factors in Croatia than in Turkey. It is extremely difficult to fully meet the expectations of each employee individually but it is necessary to establish rules and behavioural patterns that are suitable for most. The research results in Croatia and Turkey determined that money is the biggest motivator for work productivity. Even though other factors are also emphasised, the economic factor remains the most important. Indeed, it is quite normal that socio-psychological factors have a lower impact on productivity in developing countries such as Croatia and Turkey. It should be noted that differences in the perception of socio-psychological factors as labour productivity impact factors were not too big and that, obviously, these factors should also be considered.

Table 2 Results summary - comparison between Croatian and Turkish research on labour productivity impact factors

\begin{tabular}{|c|c|c|c|}
\hline Economic factors & $\begin{array}{l}\text { Rll - Turkish } \\
\text { research }\end{array}$ & $\begin{array}{l}\text { RII - Croatian } \\
\text { research }\end{array}$ & $\begin{array}{l}\text { Croatian } \rightarrow \text { Turkish } \\
\text { results }\end{array}$ \\
\hline Cash bonuses & 3,86 & 3,95 & $\uparrow$ \\
\hline Job security & 3,69 & 3,79 & $\uparrow$ \\
\hline Regularity of salary & 4,41 & 4,25 & $\downarrow$ \\
\hline Size of the salary & 4,13 & 4,06 & $\downarrow$ \\
\hline Social security & 4,03 & 3,31 & $\downarrow$ \\
\hline Average: Economic factors & 4,02 & 3,87 & $\downarrow$ \\
\hline \multicolumn{4}{|l|}{ Socio-psychological factors } \\
\hline Job satisfaction & 3,66 & 4,17 & $\uparrow$ \\
\hline Relationships with colleagues & 3,38 & 3,85 & $\uparrow$ \\
\hline Assigning Responsibilities & 3,34 & 3,40 & $\uparrow$ \\
\hline Sharing and solving challenges & 3,21 & 3,38 & $\uparrow$ \\
\hline Distance from the residence & 2,56 & 2,94 & $\uparrow$ \\
\hline Social activities possibilities & 3,19 & 2,56 & $\downarrow$ \\
\hline Working discipline & 4,17 & 3,55 & $\downarrow$ \\
\hline Health and safety conditions & 3,74 & 3,38 & $\downarrow$ \\
\hline $\begin{array}{l}\text { The creation of a competitive } \\
\text { environment }\end{array}$ & 3,53 & 3,03 & $\downarrow$ \\
\hline Cultural and national differences & 3,18 & 2,32 & $\downarrow$ \\
\hline $\begin{array}{l}\text { The participation of workers in } \\
\text { decision-making }\end{array}$ & 2,96 & 2,89 & $\downarrow$ \\
\hline Distance from the urban centers & 2,45 & 2,25 & $\downarrow$ \\
\hline Average: Socio-psychological factors & 3,28 & 3,14 & $\downarrow$ \\
\hline
\end{tabular}

Nahod, M.-M., Knezović, M. 


\section{References}

[1] Changali, S.; Mohammad A.; Nieuland, M. 2015: The Construction Productivity Imperative, McKinsey \& Company, <http://www.mckinsey.com/industries/capital-projects-and-infrastructure/our-insights/theconstruction-productivity-imperative>, Accessed 28 December 2016

[2] Adams, J.S. 1965: Inequity in social exchange. In: Advances in Experimental Social Psychology: L.N. Brewick (Ed.). 2, New York, Academic Press, pp. 267-300.

[3] Pritchard, R.D. 1969: Equity theory: a review and critique, Organisation Behaviour and Human Performance, 4, pp. 176-211. https://doi.org/10.1016/0030-5073(69)90005-1

[4] Adrian, J. 1990: Improving Construction Productivity Seminar, Associated General Contractors of America, Minneapolis, MN.

[5] Herzberg, F., Mausner, B. 1959: The Motivation to Work, John Wiley \& Sons, New York.

[6] Fiske, D. W. 1949: Consistency of factorial structures of personality ratings from different sources, Journal of Abnormal and Social Psychology, 14, pp. 329-344.

[7] Halloran, J. 1978: Applied Human Relations, Prentice Hall, New Jersey.

[8] Hanna, A.S., Taylor, C.S., Sullivan, K.T. 2005: Impact of extended overtime on construction labour, Journal of Construction Engineering and Management, 131 (6), pp. 734-739.

[9] Ng, S.T., Skitmore, R.M., Lam, K.C., Poon, A.W.C. 2004: Demotivating factors influencing the productivity of civil engineering projects, International Journal of Project Management, 22, pp. 139-146. https://doi.org/10.1016/S0263-7863(03)00061-9

[10] Završki, I. 1992: Mjerenje utjecaja faktora koji djeluju na produktivnost rada u građevinarstvu, Master's thesis, Zagreb, Faculty of Civil Engineering University of Zagreb (in Croatian)

[11] Bowie A, Lupton T. 1973: Job and Pay Comparison: How to Identify Similar Jobs in Different Companies and Compare their Rates of Pay, Gower Press, Essex.

[12] Oglesby, C.H., Parker, H.W., Howell, G.A. 1989: Productivity Improvement in Construction, McGraw-Hill, New York.

[13] Sweis, G. J. 2000: Impact of conversion technology on productivity in masonry construction, PhD thesis, Northwestern University, Evanston, IL.

[14] Kazaz, A., Ulubeyli, S. 2007: Drivers of productivity among construction workers: A study in a developing country, Building and Environment, 42, pp. 2132-2140. https://doi.org/10.1016/i.buildenv.2006.04.020

[15] Gundecha, M.M. 2012: Study of Factors Affecting Labour Productivity at a Building Construction Project in the USA: Web Survey, PhD thesis, North Dakota State University, Fargo, ND.

[16] Cheung, S.O., Suen, H.C.H., Cheung, K.K.W. 2004: PPMS: A web-based construction project performance monitoring system, Automation in Construction, 13 (3), pp. 361-376. https://doi.org/10.1016/i.autcon.2003.12.001

[17] lyer, K.C., Jha, K.N. 2005: Factors affecting cost performance: Evidence from Indian construction projects, International Journal of Project Management, 23, pp. 283-295. https://doi.org/10.1016/i.jproman.2004.10.003

[18] Ugwu, O.O., Haupt, T.C. 2007: Key performance indicators and assessment methods for infrastructure sustainability-A South African construction industry perspective, Building and Environment, 42 (2), pp. 665680. https://doi.org/10.1016/j.buildenv.2005.10.018

[19] Thomas, H.R., Riley, D.R., Sanvido, V.E. 1999: Loss of labour productivity due to delivery methods and weather, Journal of Construction Engineering and Management, 125 (1), pp. 39-46.

[20] Maslow, A. 1943: A Theory of Human Motivation, Psychology Review, 50 (4), pp. 370-396

Nahod, M.-M., Knezović, M. 